\title{
ON THE AGENDA? THE MULTIPLE STREAMS OF BREXIT-ERA UK CLIMATE POLICY
}

\author{
Jeremy F. G. MOULTON* \\ James SILVERWOOD**
}

\section{Abstract}

This article focuses on the future of UK climate action in light of the decision to withdraw from the EU. The UK's decision to leave the EU sent shockwaves through the UK and the EU political establishments and policy communities. Uncertainty marks the future of policy areas in which the UK previously demonstrated leadership. One area of particular importance is that of UK climate action. In 2006, a decade prior to the referendum in which 52\% of voters chose to leave the EU, the UK began a period of intense and ambitious climate policy development and adoption. This period of ambition drove both the UK and the EU into a position of global climate leadership. Brexit has the potential for significant impact on the UK's climate policy. However, political debates about the UK's post-Brexit future have largely been devoid of references to climate change. Drawing on the agenda-setting literature, this article deploys the multiple streams model to analyze the problems, politics and policies of Brexit-era UK climate action. This is an innovative utilization of the multiple streams model, which is primarily used to explore policy change retrospectively. The application allows for the addressment of key issues - whether Brexit signals a definitive break in UK climate action, whether there is still support for climate action in Brexit Britain, and the future institutional capacity for climate policy. It is concluded that the $U K$ is sleep-walking into diminished climate actorness after it leaves the EU.

Keywords: Brexit, climate action, multiple streams model, European Union.

\footnotetext{
* Ph.D., Department of Politics, University of York, e-mail: jeremy.moulton@york.ac.uk (corresponding author).

** Ph.D., School of Strategy and Leadership, Coventry University.
} 


\section{GÜNDEMDE Mİ? BREXIT DÖNEMİ BİRLEŞIK KRALLIK İKLIMM POLITIKIKASININ ÇOKLU AKIŞI}

\section{$\ddot{O} z$}

Bu makale Avrupa Birliği'nden (AB) ayrılma kararı ışı̆̆ında Birleşik Krallık (BK) iklim eyleminin geleceğine odaklanmıştır. BK'nin AB'den ayrlma kararı hem $B K$ hem de AB siyasi müesseselerini ve politika topluluklarını şaşkınlığa uğratmıştır. Evvelce BK'nin liderlik gösterdiği alanların geleceğine şimdi belirsizlik damga vurmaktadır. BK iklim eylemi özel öneme sahip bir alandır. 2016'da, seçmenlerin \%52'sinin ayrlma yönünde oy verdiği referandumdan on yıl önce, BK iddiall ve hummal bir iklim politikasl geliştirme ve benimseme dönemini başlatmıştl. Bu iddialı dönem hem BK'yi hem de AB'yi küresel iklim liderliğine yöneltmişti. Brexit BK'nin iklim politikasında önemli etkiler yaratma potansiyeline sahiptir. Bununla birlikte, BK'nin Brexit sonrası geleceği ile ilgili siyasi tartışmalarda iklim değişikliği büyük ölçüde es geçilmiştir. Bu makale gündem-belirleme yazınına dayanarak çoklu-akış modelini Brexit sonrası BK iklim eyleminin sorunların, siyasetini ve politikalarını incelemek için kullanmaktadır. Bu, esas olarak geçmişe dönük politika değişimini keşfetmek için kullanılan çoklu-akış modelin yenilikçi bir uygulamasıdır. Bu uygulama ana meseleleri irdelemeye imkan vermektedir: Brexit BK iklim eyleminde bir ayrım noktasını mı işaret etmektedir yoksa Brexit BK'sinde hala iklim eylemine ve iklim politikasının kurumsal kapasitesinin geleceğine destek var midır? Bu makalede BK'nin AB'den ayrlmasının ardından güçten düşmüş bir iklim aktörlüğ̈̈ne doğru uykuda yürüdüğ̈̈ kanaatine varılmıştır.

Anahtar Kelimeler: Brexit, iklim eylemi, çoklu-akış modeli, Avrupa Birliği.

\section{Introduction}

The result of the $23^{\text {rd }}$ June 2016 referendum on the UK's membership of the European Union (EU) sent shockwaves through both the UK's and the EU's political establishments and policy communities. The stability of a number of key policy areas has been called into question by the result and the UK government's subsequent decision to trigger Article 50 of the Treaty on European Union. One such key policy area is climate action. The UK and the EU have championed responses to a changing climate, attempting to offer global leadership on the subject. That record of leadership is now under threat due to Brexit.

Understanding the potential of post-Brexit domestic climate action is vital. There is already considerable scepticism around the future of 'green' policy 
fields in the UK. As Carter and Childs stress: "Brexit means that UK environmental and climate change policy is facing huge uncertainty and instability" (2017: 18). The uncertainty and instability revolve around the form, ambition and legislative construction of post-Brexit UK climate policy. Whether the UK will continue to participate in EU-level climate action, whether the UK will increase its ambition in response to climate change or whether the transition to Brexit will lead to backsliding on climate action - these are all key issues surrounding the matter.

In this article, we turn to the agenda-setting literature deploying Kingdon's multiple streams model (1995) in order to analyze the problems, politics, and policy of UK climate action in the Brexit era and the potential for policy change in this period. This application of multiple streams constitutes an innovative deployment of the model, which is usually applied retrospectively to analyze change in policy. The uniqueness and benefit of our utilization of the multiple streams model is that it allows for the examination of a policy area before it is has reached the political agenda. Additionally, this provides the opportunity to examine the streams of the policy field at later points, for example after radical policy change, in order to better analyze and understand the policy-making process.

The article continues with an introduction to Brexit and UK climate policy. The multiple streams model is detailed, introducing the three streams that make up the model, along with the concept of 'policy entrepreneurs'. We then turn to analyze each of the streams in turn in relation to Brexit and UK climate policy. Finally, it is concluded that whilst climate action is firmly off the agenda in the Brexit era, policy change is on the verge of happening by stealth. As this paper details, key aspects of EU-level environmental legislation will not be brought into UK law and nor will EU treaty principles - both have been key factors in shaping UK climate and environmental policy in previous decades. This has the potential for creating radical change to the UK's environmental policy. Up to $55 \%$ of UK greenhouse gas emissions (GHGE) reduction efforts could be affected by these changes, yet contemporary UK politics remains near-devoid of substantial reference to climate change. In conclusion, the UK is sleepwalking into post-Brexit diminished climate actorness.

\section{Brexit and Climate Action}

Since the 1970s, the wide scope of UK politics and policy has been shaped by its membership of the European community. That the population of the EU's third largest Member State would choose a future outside of the block has extensive implications for the UK and for the EU itself. Eurosceptic commentators across Europe were quick to label the referendum result as the first concrete step towards the unravelling of the European project. The anti- 
immigration and anti-establishment sentiments that drove many Leave voters have found increasingly receptive audiences in the EU's other 27 Member States (Hobolt, 2016). It is of little surprise that the UK would be the first to turn towards the exit, however, given the country's long-standing Euroscepticism and the sense of its "otherness" within the European system.

Britain long had the reputation of being an "awkward partner" in the EU (Buller, 1995). To opponents of the UK's membership of the EU, this label of awkwardness reinforced the notion that the UK and the EU were not entirely suited to one another. For proponents, this awkwardness was either a key aspect of shaping the EU polity or in fact a fantasy. The arguments were, in part, fought over two sides of the same data. Leave campaigners called on the fact that in the European Council (the intergovernmental institution of the EU's codecision procedure) the UK was the most outvoted Member State. Remain campaigners could and did respond that the UK in fact voted in favour of $97 \%$ of EU legislation between 2004-2016 (Hix, 2016). Nevertheless, the narrative that the UK was apart from the "European family", constantly pushing against amassed EU policy priorities, was a powerful one. Furthermore, it is one that is also likely to guide post-Brexit legislation. The European Union (Withdrawal) Bill 2017-2019, as crafted by Prime Minister Theresa May's Government, plans for the wholesale adoption of EU regulations as UK law after the country's exit from the EU. However, parts of EU-level legislation (such as climate legislation) would not necessarily be included in this. In the longer term, there is the question as to whether Brexit will lead to wide-scale scrapping of legislation - a 'bonfire of the regulations' described by Coulter and Hancké (2016).

In the years before the referendum, EU climate action was portrayed as having particularly burdensome regulation, even within the ranks of the EU institutions. Former European Commissioner for Industry, now President of the European Parliament, Antonio Tajani, remarked in 2013, "we face a systematic industrial massacre... We have to stop pretending, because we can't sacrifice Europe's industry for climate goals that are not realistic, and are not being enforced worldwide" (quoted in Evans-Pritchard, 2013). In the same year, the Conservative Prime Minister David Cameron was part of a similar backlash against the costs incurred due to climate legislation (Carter and Clements, 2015). One might expect, then, that climate legislation would be the first on the bonfire. Yet, given the UK's patchy history of climate action, the picture is not entirely clear.

Despite being an early mover on climate action, the UK has been described as "a paradoxical leader" on the matter (Rayner and Jordan, 2011: 95). It has provided both global and EU leadership in reducing GHGE. It was the only EU Member States to take on a higher emissions target after the Kyoto Accord 
(Jordan et al, 2010). The UK's Climate Change Act (2008) (CCA), which set legally-binding GHGE reductions for 2050, was a pioneering policy creation. Even as recently as 2017, the UK was assessed as being one of the top three countries for climate action efforts in the Climate Change Performance Index (Burck et al, 2016). Prime Minister Margaret Thatcher was one of the first prominent global leaders to speak on the causes and dangers of the changing climate (Thatcher, 1989). Yet, subsequent major UK GHGE successes cannot be attributed to climate actorness. Instead, the "dash for gas" in the 1990s, wherein the UK partly shifted away from coal-fired power stations towards gas, was a primary driver of GHGE reductions. Moreover, ambition has not always led to realized policy successes. The fuel duty escalator, created to slowly decrease vehicle use in the UK had to be scrapped in 2000 because of fierce public opposition. A $20 \%$ GHGE reduction goal for 2010 was quietly dropped when it became apparent the target would not be met (Rayner and Jordan, 2017). The claim of the 2010 coalition between the Conservatives and Liberal Democrats that theirs would be "the greenest government ever" was also soon surrendered, leading Carter and Clements to wonder if the pledge simply represented a "rash moment of bravado" (2015: 220) for Cameron.

Given the varied record of the UK on climate action and the enthusiasm for reducing the regulatory burden on the UK post-Brexit, the question of whether the UK will maintain its climate actorness is a pertinent one. UK climate ambition began to decline in the years prior to the referendum (Carter and Clements, 2015). The transition to Brexit could then continue or even accelerate this trend. The future of UK climate policy is also important to the EU's future. It is an accepted principle of the EU's environmental action that such problems are best tackled in a transboundary manner due to their transboundary nature (Grant et al, 2000; Debelke and Vis, 2015). Its environmental and climate action has shaped the EU as a distinct actor alongside its constituent Member States (Vogler, 2011: 23), whilst also being a basis through which to legitimate its power (Moulton, 2016). For the UK to break from the EU on climate action would, then, be a tear in the justification for the EU Member States' pooling of sovereignty.

Having provided the context of Brexit and UK climate action, this article continues with an introduction to the multiple streams model. The application of this model is subsequently used to assess Brexit-era UK climate action. We define the Brexit era as one that began with the victory for the Leave campaign in the $23^{\text {rd }}$ June 2016 referendum. It is a period of British politics distinct from that preceding it in the quality, tone and substance of the debate. Examining the possibility of policy change resulting from this period is an important undertaking. Whilst the UK may only account for just less than $2 \%$ of global emissions (Department for Business, Energy \& Industrial Strategy: 2017a), it 
has had an oversized influence on global climate politics through its leadership. Understanding the potential future of UK climate action is therefore vital also to the future of international climate politics.

Lastly, it is important to stress that whilst this article is written and researched on the assumption that the UK will leave the EU, there is an increasing level of scepticism about the inevitability of this outcome. One mainstream party leader has suggested that the UK will not in fact exit the EU. However, we continue on the assumption that the UK will leave - whether it be on $31^{\text {st }}$ March 2019 or later.

\section{The Multiple Streams Model}

The multiple streams model, developed by Kingdon in Agendas, Alternatives, and Public Policies (1995), was the culmination of a four-year research project into policy-making in the United States' Congress. Kingdon sought to answer a question that lies at the heart of policy making - how does an idea's time come? Kingdon was animated to understand why certain issues come to the fore over others, how agendas are set, when policy windows open, and what it is that allows for them to open. Kingdon sought to explain why long periods of relative inactivity in a given policy field can suddenly be interrupted with periods of lively activity. Baumgartner and Jones describe this process, in their separate model of agenda setting, as punctuated equilibrium (2009).

This generalized characterization of policy change is one that clearly corresponds to the development of climate policy. Climate action is often the realization of what is politically possible, not what is scientifically necessary (O'Riordan and Jordan, 1996: 77). Levin et al (2012: 123) define climate change as a 'super wicked problem', that is, one where time is running out; those who cause the problem are seeking to provide a solution; the central authority needed to confront the problem is weak or non-existent; and where irrational discounting pushes the burden of response onto the future. Therefore, any information that might guide the exploitation of future policy windows is vital to ensuring policy entrepreneurs can confront the super wicked problem at hand, avoiding the compromise that likely constitutes an acceptance of still majorly disruptive climatic change. In this case, the multiple streams model is utilized to analyze the potential of UK climate policy.

Kingdon conceptualized the policy-making process as consisting of three streams - problems, politics and policy. When these three streams converge, a policy window opens allowing for change. As he described, policy change occurs when "people recognize problems, they generate proposals for public policy changes, and they engage in such political activities as election campaigns and pressure group lobbying" (1995: 197). In other words, the convergence of the three streams occurs when a policy problem has been 
identified as needing a solution, when a suitable solution is available, and when there is the political will/ capital needed in order to institute that solution. Each of the respective streams is seen as "largely separate from the others, with its own dynamics and rules" (Travis and Zahariadis, 2002: 496).

The problem stream can be considered active when there is an identifiable problem to which a solution is recognized as necessary. Kingdon lists different ways that actors might identify the existence of such a problem:

Sometimes their attention is affected by a more or less systematic indicator of a problem. At other times, a dramatic event seizes their attention, or feedback from the operation of existing programs suggest that all is not well' (1995: 90).

However, on its own, the existence of a problem is not enough for the problem stream of the model to be identified as active. According to Kingdon,

whether a problem really is a problem at all is an important part of political and policy debate: merely stating a problem is not enough, one must persuade others that the problem exists or that the problem being cited is the real problem (1995: 90).

As a result, the identification of a problem and its framing are vital to the development of political will to solve the problem. Additionally, framing will shape the form of subsequent policy solutions. Indeed, Mintrom asserts that for policy entrepreneurs "problem definition is a key task" (2000: 43). That is, efforts towards actorness are likely to be markedly limited if they are not supported by a correctly defined problem.

The politics stream includes what is politically possible at a given moment. Kingdon considers the 'political' narrowly as in 'electoral, partisan, or pressure group factors" (1995: 145). This stream is understood as being fluid and subject to shifts in public mood, ideology, pressure group campaigns and election of new governments, which can all have a "powerful effect on agendas, as new agenda items become prominent and others are shelved until a more propitious time" (Kingdon, 1995: 145). Within the politics stream there can be a blurring of the lines between policy entrepreneurs and policy-makers, as those that exploit the rise of issues onto the agenda may also be those who play a key role in selecting and shaping that policy (Ackrill, 2013). This blurring of distinctions is one that is particularly relevant in Brexit-era politics.

The policy stream is considered active at the culmination of a process wherein specialist communities of policy-makers have developed, proposed, and negotiated different policy solutions. Kingdon describes this culmination as, "when a large number of possible policy initiatives is narrowed down to a short list of proposals that are seriously considered" (1995: 143). The actors at work within this process are described as "a community of specialists: 
researchers, congressional staffers, people in planning and evaluation offices and in budget offices, academics, and interest group analysts" (Kingdon, 1995: 116). This non-exhaustive list is clearly focused on the US case study through which the multiple streams model was developed. Although the institutional titles differ in the UK, and although a more prominent role exists for environmental protest groups (EPGs), this roughly correlates to the list of actors one might expect to formulate climate policy in the UK. In clear terms, the policy stream represents the discovery of a fitting policy solution to a given policy problem.

The convergence of these three streams alone is not enough to ensure policy change. Kingdon proposes that policy entrepreneurs are vital to exploiting the policy windows opened by the convergence of the three streams. Policy entrepreneurs are described as "people willing to invest their resources in return for future policies they favour" (1995: 204). Resources can include time, money, reputation and energy (1995: 176). There is no one group of actors who are the policy entrepreneurs. Instead, politicians, civil servants, academics, journalists, lobbyists, and pressure-group campaigners are all examples of potential policy entrepreneurs. The motivations of these actors are varied, and can range from the selfish to the selfless. Regardless of their position, their motivation, or the resources they put to the task, these actors are key to the bringing together of the three policy streams in order to enact policy change. The importance of policy entrepreneurs for the development of climate action is well established (Kern and Bulkeley, 2009). However, it should also be noted that substantial climate action cannot be driven by policy entrepreneurs alone:
... while policy entrepreneurs are critical at the start of a policy process, in order to overcome the constraints of administrative structures, party politics and political timetables, and to survive the loss of particular individuals, a broader institutional capacity for climate protection is necessary (Bulkeley and Kern, 2006: 2253).

This finding, on the importance of institutional capacity for climate action, is of particular relevance and usefulness in the current analysis. A key concern around Brexit and climate action is the decline of the UK's institutional capacity to respond to a changing climate as much of such capacity has been amassed at the EU-level. This will be expanded on in the following analysis.

The simplicity, clarity, and analytical usefulness of the multiple streams model has meant that it has become established as a popular and influential framework for analyzing agenda setting (Béland and Howlett, 2016). It is for these reasons that the model is used here over other popular alternative models for agenda-setting, such as punctuated equilibrium theory, which does not allow for the same range of foci. Although the model was initially developed in the analysis of US policy making, its application has not been constrained by the 
structural and functional specificities of this founding case. Instead, it has been applied in the analysis of a range of different national contexts and at different levels of governance (Jones et al, 2016). Kingdon's work has been usefully applied in the analysis both of UK climate and energy policies (Lovell et al, 2009), as well as broader European climate action (Keskitalo et al, 2012).

Whilst subsequent contributions by others have tried to build on Kingdon's foundation by creating four and five stream models for subsequent stages of the policy process (Howlett et al, 2015), the three streams of the multiple streams model remain the dominant approach to analyzing policy creation. The founding of the model has been criticized as being overly dependent on "a single, somewhat idiosyncratic national case" (Béland and Howlett, 2016: 222). This criticism of Kingdon's model is based on its perceived limits when applied in comparative study due to its single case subject of the US congress. This current analysis will not have a comparative element so we do not open up the framework to other policy theories or models in order to build on the study; as has been done, for example, by Spohr (2016) and Zohlnhöfer et al (2016). We are also of the opinion that a 'somewhat idiosyncratic national case' is a suitable descriptor for Brexit and the UK, making us especially certain that this model is a suitable fit for the study at hand. The following section turns to the analysis of Brexit-era UK climate policy, through the application of the multiple streams model.

\section{The Multiple Streams of Brexit-Era UK Climate Policy}

The climate policy outcomes of the Brexit process are by no means clear or settled. There are a range of possible outcomes for climate action during the Brexit era. Post-Brexit climate action may closely correspond with the preBrexit system, with the UK and EU cooperating in target-setting and the use of policy instruments such as the EU Emissions Trading System (EU ETS). Alternatively, the UK might decide to "go it alone" on climate action, establishing independent policy instruments, perhaps a UK ETS. In this second scenario, there are further contrastable outcomes. Firstly, that the UK will mirror the EU level of ambition on climate action. Secondly, that the UK will adopt climate policy that is more ambitious than the EU's. Thirdly, that the UK will let climate action regulatory standards slip, perhaps in an effort to attract short-term economic reward. Deploying the multiple streams model, we draw conclusions as to the most likely of these outcomes. The model is a particularly useful application in this case. It is apparent that outcomes will be shaped entirely by how the problem is framed, what political will is in place for solutions and which policy solutions are available.

The multiple streams model has been applied to the development of climate policy in previous studies. Indeed, to give a particularly relevant example, 
Carter and Jacobs (2014) have used the multiple streams model to explain radical climate policy change in the UK between 2006-10. Similarly, Brunner (2008) has applied the model to understand radical changes in Germany's emissions trading system. However, these studies applied the model in a retrospective manner, analyzing past policy developments. Here we propose and utilize an innovative application of the multiple streams model. Analyzing the problems, politics, and policy of Brexit-era UK climate policy, conclusions have been developed as to the foreseeable future of climate policy in the UK. Additionally, we propose that subsequent studies, utilizing the same model and case, might build on this application of the multiple streams to track the snaking of the three streams towards ultimate convergence - whenever that may be.

We continue by analyzing the three streams of the multiple streams model in turn, exploring the key factors relating to the case of Brexit-era UK climate policy.

\section{The Problem Stream}

As previously stated, there are three ways in which an issue can come to the attention of actors and become identified as a problem in need of a solution. Firstly, attention might be attracted by a systematic indicator of a problem. Secondly, a dramatic event can catch attention. Kingdon classes such moments as "focusing events" (1995: 94). Thirdly, feedback on current practices might indicate that all is not well. Exactly which problem is in need of identification is a key question in this case. Climate change itself has been identified as a problem and already elicited responses. However, the problem to be identified could be failings within the current EU policy arrangement. Alternatively, it could be that the UK withdrawing from the EU policy arrangement and "going it alone" on climate is the problem. The framework is applied here in order to explore the potential identification of problems in this case.

Additional to the three manners of problem identification, framing is also an integral aspect of the problem stream. In the UK, climate change as a policy problem has already been framed as it has in much of the world. That framing is not along the lines of ecological thought, which would champion climate action on the basis of our duty to safeguard the non-human world based on its intrinsic value. Instead, the identification of value in the debate and framing around climate change has largely focused on monetary value and similar economistic devices (O'Brien and Wolf, 2010; Lee et al, 2012; Davies et al, 2016; Willis, 2017). Carter and Jacobs (2014) describe The Stern Review on the economics of climate change as one of the focusing events that contributed to a wider acknowledgement of climate change as a severe policy problem and, thus, onto the UK's policy agenda. The report, ordered in 2005 by Chancellor of the Exchequer, Gordon Brown, is a near 700-page investigation into the monetary 
costs of climate change. Whilst the report does make mention of the catastrophic human cost of climate change, its primary conclusion was that the economic cost of action is only a fifth of the cost of inaction (Stern, 2006: vi). This conclusion became part of the basis for the justification of the CCA in the UK, which demonstrates that climate change has and can be packaged as a policy problem that elicits solutions in the UK.

Turning to the first manner of problem identification - there are indicators that current EU-level policy is not performing at the level it was designed to perform at. One particular problem area is the EU ETS, a flagship piece of EU climate policy. The system covers around $45 \%$ of the GHGE in the EU, which includes emissions from over 11,000 energy-intensive installations and airlines (European Commission, 2016). The EU ETS is a classic cap-and-trade-style policy instrument, wherein a cap on total GHGE is set and is slowly reduced. Emissions within the cap have to be covered by allowances, which are available on the market or initially provided to companies without charge. The public nature of the market provides a clear indicator of the success or failure of the system. Whilst it was initially hoped that the price per allowance (which corresponds to one tonne of GHGE) would be around $€ 30$, the price crashed within two years of trading opening (Hintermann, 2010). The price has remained stubbornly low since, therefore not providing the desired incentive to businesses to cut their GHGE. This is especially troubling as, to meet 2050 GHGE reduction goals, the allowance price should be over $€ 200$ by 2020 (Babonneau et al, 2016). At the current rate of development, that price looks highly unlikely. This is a clear and prominent indicator of problems in EU climate policy, and one that could contribute towards the UK withdrawing from the system. This potential withdrawal would be less likely if the EU ETS were functioning properly (Brunsden and Baker, 2017; Sandbag, 2017; Ward and Carvalho, 2017).

There are also positive indicators of EU climate policy successes, however. For example, total GHGE levels in the EU-28 reduced from over 5.7 million tonnes in 1990 to under 4.5 million tonnes in 2015. This constitutes a $22.1 \%$ reduction, already surpassing the EU's 2020 goal. During the same period, UK emissions fell by $38 \%$, whilst its economy grew by $64 \%$ (Department for Business, Energy and Industrial Strategy, 2017b). Therefore, there are indicators that GHGE efforts are successful under the current policy regime.

Turning to focusing events, with the furor around Brexit and the resulting upheaval in Westminster politics, there has been little political oxygen or print space left for climate change in the UK in the Brexit era. As Kingdon writes,

Problems are often not self-evident by the indicators. They need a little push to get the attention of people... That push is sometimes provided by a focusing event like a crisis or disaster (Kingdon, 1995: 94). 
Three months after the EU referendum, the world's environment permanently passed the 400ppm carbon dioxide threshold (Kahn, 2016). This $400 \mathrm{ppm}$ is largely symbolic, but the threshold had long been expected as a clear indicator of the anthropogenic and radical changing of the world's climate. In normal political times, this event might have had the capital to be a focusing event. In the UK the story barely registered. The unique global political climate, dominated by news from the US presidential election and UK political fallout from Brexit, meant the story similarly failed to gain attention. Certainly, there has been no climate 'crisis or disaster' which has pushed climate change onto the UK agenda in any notable way.

This has occurred despite a plethora of feedback on climate in the period since the referendum on Brexit and its impact on climate action. Climatefocused think tanks, such as E3G and Sandbag, have published prominent reports into the potential future of UK climate action (Clutton-Brock, 2017; Sandbag, 2017). The main takeaway from many of these publications is that there are no practical or legal reasons as to why Brexit must necessarily lead to a decline in UK climate action. As one piece from Jonathan Gaventa of E3G stated, "in principle, it should be both possible and desirable for the UK to emerge from the Brexit process with just as strong position on climate and clean energy as before" (2017) (emphasis added). Certainly, with the CCA, the UK has a framework in place that could ensure long-term GHGE reductions are reached. Yet, whilst there is no reason that a decline in climate action and Brexit must go hand-in-hand, a groundswell of feedback has pushed the conclusion that this is a highly possible outcome of the process.

Noting the strength of the CCA in a policy paper submitted to the House of Lords, however, Ward and Carvalho (2017) still warned that Brexit 'may have an impact on the achievement of the targets set out under the Act and associated legislation and regulation'. Additionally, the Committee on Climate Change (2016), an independent, statutory body established under the CCA, has noted that EU-level climate action legislation could account for $55 \%$ of GHGE reductions required in the UK by 2030 . These are emissions which are not currently governed by the CCA or other UK legislation, leaving the severe possibility of a post-Brexit policy gap. Furthermore, the Withdrawal Bill will only transpose directly-applicable EU legislation. Principles which are written into the EU treaties, that have substantially shaped decades of UK and EU climate and environmental policy, will not be signed into UK law as part of the bill (Petetin, 2017). The use of the precautionary principle, for example, has been vital to the development of ambitious climate and environmental policy in the UK and the EU. Although the EU has not always had an entirely coherent conceptualization of the principles behind its environment and climate action (Connelly, 2012), the principles have remained an important aspect of its 
actorness. Their legislative absence in the UK could be expected to reduce any legal drive for stringent climate policy.

Examining the problem stream of Brexit-era UK climate action, it is not apparent that one problem is coming to the fore over others. The lack of a clearly defined problem reduces the likelihood that climate change will come on to the policy agenda in the near-future. Whilst problems certainly do exist with contemporary EU climate policy, the UK has played a prominent role in the development of that policy. It therefore seems unlikely that criticism of the current EU model would form the basis of a drive for a radically different form of climate policy in the UK. The clearest sign of a problem with climate policy comes through the feedback indicator. The policy gap that Brexit is likely to create, with an absence of key principles and EU-level regulation in post-Brexit UK's legal framework, seems poised to usher in a diminution of climate action in the country. However, despite the severity of this problem there seem to be few prominent actors or policy entrepreneurs willing to push the issue. This lack of willingness to identify the slow-slide into diminished UK climate action is likely due to the politics stream, which is explored next.

\section{The Politics Stream}

The previous section found there to be little activity in the problem stream of UK climate action in relation to Brexit. However, the creation of a policy window can be triggered primarily by developments in the politics stream, as it drives the convergence of the problem and policy streams (Brunner, 2008). Kingdon writes that changes in the political stream "have a powerful effect on agendas, as new agenda items become prominent and others are shelved until a more propitious time" (1995: 145). Therefore, examining this stream in relation to the current subject provides the highest possibility of insight on the likelihood of climate change reaching the policy agenda.

The Brexit era has been marked by radical changes to the political stream, so radical that it has been claimed that UK has become 'ungovernable' (Moore, 2017) and that 'Brexit has broken British politics' (Stephens, 2017). As mentioned in the above section, this has left little oxygen for other political issues. Certainly, the zeitgeist is not one marked by zeal for climate action. Given the divide that the referendum cleaved in the UK, it is most pertinent to suggest that the future of the UK's relationship with the EU over climate change is more likely to be shaped by political concerns of sovereignty than it is concerns over climate action itself (Jessop, 2017). Sandbag, a UK-EU climate change think tank, made this assertion with the justification that for policy entrepreneurs in the UK there's an 'absence of a clear-cut solution' (2017). Whilst there is, of course, the chance that the regulatory upheaval of Brexit could be used to enact more ambitious climate action, this possibility must be 
tempered with political reality: "While [Brexit] presents the opportunity for more efficient or more ambitious climate policy, it is unclear whether the political appetite for this is particularly strong" (Hepburn and Teytelboym, 2017: S146). Within Westminster it would appear that climate action is not a prominent consideration in Brexit-era politics.

On the $29^{\text {th }}$ March 2017, UK Prime Minister Theresa May wrote a sevenpage letter to the President of the European Council, officially notifying him of the UK's decision to leave the EU. This was the first step in the formal process of leaving the EU, as detailed in Article 50 of The Treaty on European Union. The letter established May's hoped-for parameters of the UK-EU relationship post-Brexit. Whilst the letter made mention of some priority policy areas - such as the economy and security - climate action was conspicuously absent. This omission was not missed in the UK media (Simms, 2017). Within May's inner circle views on UK climate action have at times been worse than absent. Nick Timothy, May's former joint Chief of Staff described the CCA as a 'unilateral and monstrous act of self-harm' (2016) due to the claim that it drove up electricity prices.

General Elections are perhaps the foremost moment for the altering or promoting of policy priorities in the UK. Not only does an election bring into office potential policy entrepreneurs, but the people outside of elected office may also feel enabled towards pushing policy onto the agenda by election results (Kingdon, 1995: 61). Climate action was, again, conspicuously absent from the $8^{\text {th }}$ June 2017 General Election campaigns. Whilst the Green Party did attempt to set themselves apart from their mainstream rivals by adopting or improving all EU environmental laws, they performed worse on this platform than they did in the 2015 election (Carter and Farstad, 2017).

As the UK's record of climate action has been patchy and at times paradoxical, so have the country's political parties shown an inconsistent enthusiasm for the matter. The CCA was passed in Parliament with an outstanding level of unity between the sitting political parties - only three MPs opposed the Act (Farstad et al, 2018). The CCA resulted from the period between 2006 and 2010 in which climate change was both prominent on the political agenda and a basis of consensus between the UK's three foremost parties (Carter: 2014). However, after Cameron's pledge that the 2010 coalition would be the "greenest government ever", tensions between the parties of government began to be exposed, with the traditionally environmentally minded Liberal Democrats more enthused by action than the Conservatives. The Conservatives have since withdrawn from climate ambition by withdrawing subsidies for onshore wind turbines, selling off the Green Investment Bank, halting the zero carbon homes scheme and removing the Department of Energy and Climate Change (Farstad et al: 2018:2). This departure from cross-party 
consensus on climate change also marked the rise of UKIP, the powerfully prominent, though not electorally successful, pro-Brexit party that questioned both the economic feasibility of climate action and the science of climate change itself. A mark of the Brexit era has been that the parties most likely to express Eurosceptic beliefs are also those likely to express climate or climate action sceptic positions. As the UK withdraws from the EU this could be interpreted as boding poorly for the political salience of climate action.

As well as party-political elements, Kingdon also identifies the importance of pressure groups in driving developments in the political stream. Environmental pressure groups (EPGs) have played a sizeable role in past UK climate action. Friends of the Earth has been identified as a policy entrepreneur in the development of CCA (Carter and Childs, 2017), for example. Having previously played a significant role in radical changes to climate policy in the UK, EPGs are again looking to play the role of driving environmental action, including on climate change, onto the UK agenda in the Brexit era. 13 major EPGs, representing a combined membership of 7.9 million people, have formed the Greener UK coalition. ThisEPG coalition is attempting to influence the UK's withdrawal from the UK in order to avoid a weakening of environmental ambition during the process (Greener UK, 2017). This consensus-building and EPG cooperation has the capacity to build considerable momentum. Kingdon stresses the influence of such interest group coalitions:

If important people look around and find that all of the interest groups and other organized interests point them in the same direction, the entire environment provides them with a powerful impetus to move in that direction (Kingdon, 1995: 150).

This coalition is one positive indication that concerted efforts are being made by aspiring policy entrepreneurs to force climate action and broader environmental action onto the Brexit-era agenda.

Public opinion is another significant factor that shapes the policy stream. Alteration in public opinion can quickly catapult an issue onto the agenda, leading to radical changes of policy. As Kingdon states of legislators, "there might be instances in which they feel the public at large virtually directs them to pursue a course of action' (1995: 52). Whilst Kingdon's model was based on US politics, public opinion has been confirmed as having a high level of impact on policy positions and the outputs of governments in the UK (John, 2006: 1054). One might expect, given the apparent absence of climate change from Brexit-era politics, that the UK public is relatively uninterested in the subject. Yet, that is not represented in the data. In fact, public concern over climate change has increased in the Brexit era. The European Commission's biannual special Eurobarometer found an 11 percentage point increase in UK respondents who labelled climate change a very serious problem between 2015 
and 2017, leaving the total at 64\% (European Commission, 2017). The UK government's own data found a similar upwards trend in the percentage of the public concerned over climate change. Statistics from the Department of Business, Energy \& Industrial Strategy found an increase of 5 percentage points between 2015-17, leading to a total of $71 \%$ of respondents expressing concern (Department for Business, Energy and Industrial Strategy, 2017c). This level of public concern makes for a striking contrast with the level of concern displayed in UK politics on the matter in the Brexit era. Perhaps the history of public marginalization on climate action in the UK, even when their involvement has been legally required (Lee et al, 2012), means that could-be policy entrepreneurs play little heed to public opinion on the issue. This contrasts with the expectations found within the multiple streams model. Alternatively, Watson has proposed that Brexit created a particular cleavage between UK voters and their representatives (Watson, 2018). This too might help explain the unresponsiveness in the political stream to the public mood on climate change.

Kingdon stresses the importance of bandwagons, tipping, and snowballing as devices for driving political capital towards a given policy aim (1995: 161). There is little evidence that any of these processes are underway in the Brexit era. There seems to be little concerted and concentrated efforts within Westminster to bring climate change into the politics of the moment. Whilst one might usually expect that public concern would push climate action on to the agenda as it increases, there seems to be little responsiveness to the matter. Because of this, there are few aspiring policy entrepreneurs to identify in the political arena. The one sector that is working to push environmental matters onto the Brexit agenda are the EPGs. The coordination and cooperation displayed by those groups is reminiscent of past successes had in the past, primarily around the CCA. However, a markedly different political climate reduces the likelihood of these substantial efforts gaining traction.

\section{Policy Stream}

Post-Brexit UK climate change policy will be determined by the degree of cooperation with the EU, which could negate the need for policy innovation. There is significant incentive for the UK to continue cooperating with the EU on climate action and maintaining much of the regulatory status quo. The particulars of the issue might make it distinct from other policy areas where the political stream is pointed towards an uncooperative relationship. As one report states:

Many issues in the negotiations over the UK's exit from, and future relationship with the EU are likely to be perceived as zero-sum-games, however, climate change and energy are areas where there is already an alignment of interests between the EU and the UK and where rapid progress towards an agreement could be made (Clutton-Brock, 2017: 1). 
However, as the previous section on the political stream stated, none of the mainstream parties have pledged such policy continuity. Instead, the most prominent government commitment with relevance to the policy stream came in the White Paper on the UK's exit from the EU. In that document, the government stated:

We will use the Great Repeal Bill to bring the current framework of environmental regulation into UK and devolved law... We want to take this opportunity to develop over time a comprehensive approach to improving our environment in a way that is fit for our specific needs (HM Government, 2017: 45).

Given that UK climate and environmental policy has developed in the EU context (Committee on Climate Change, 2016), the policy community will be specialized in that legislative context. Preparing to rewrite environmental policy 'in a way that fits our specific needs' will be particularly challenging because of this EU-focused specialization. It is likely to require the creation of new policy communities. The weakness of the UK's civil service has been flagged as an up-coming crisis of the post-Brexit UK's institutional capacity (Jessop, 2017: 138). Even if environmental and climate policy areas were political priorities, this diminished institutional capacity would mean policy solutions would be slow to arrive. That they are not casts considerable doubt over the future of policy development in this field. As one report stated, 'the process of leaving the European Union is likely to tie up significant institutional capacity that could negatively impact many policy areas, including climate change mitigation and adaptation' (Ward and Carvalho, 2017). This low level of institutional capacity and attention that can be provided to climate action means that the innovative policy responses that Brexit will likely necessitate are unlikely to be forthcoming.

In the development of past climate policy, credibility gaps have frequently emerged, wherein public commitments to action have not been matched with actual policy change (Demeritt and Langdon, 2004). These rhetorical commitments can in themselves count as policy solutions by effectively closing policy windows. Howlett et al argue that the appearance of addressing a policy problem can supersede the solving of the problem itself, "public policy is driven not just by the need to solve problems, but also by the political need to be seen to address problems - even at the expense of failing to solve the problem itself' (Howlett et al, 2015: 423). However, given the distinct lack of public attention to solving the policy problem of climate change, it would seem unlikely that rhetorical commitments could count as policy solutions in this case.

Finally, whilst Kingdon proposed a list of potential members of the policy community, the actors that would most shape the policy stream, the 
peculiarities of this case have seen the influence of these communities diminished. The pre-referendum and Brexit era are marked by a stark resistance to such specialized actors. As Michael Gove, a prominent Leave campaigner and government minister described, "people in this country have had enough of experts" (quoted in Mance, 2016). The possibility of the policy stream becoming active is further reduced due to this factor.

\section{Conclusion}

The innovative utilization of Kingdon's multiple streams model in a nonretrospective analysis has provided the opportunity to analyze Brexit-era climate action in the UK. The exploration of the policy potential through the analysis of the problem, politics, and policy streams has revealed important findings about the state and probable future of the field. Express opposition to climate action, of the type displayed in 2013, both in the UK and the EU executive, as well as by key political figures at later points, is not part of the agenda. This is a small cause for optimism. However, whilst the knives are not out for climate action as the UK exits the EU, substantial harm may still be inflicted. We have found that the politics stream is the predominant of the three streams, with the Brexit era political atmosphere stifling climate action, as it is likely doing to a range of other policy areas, meaning that the policy window is likely to remain closed for the foreseeable future. Concerns over the post-Brexit future of UK climate action are not misplaced. Whilst there is not a public, concerted effort within the UK government to put climate action on the "bonfire of regulations' (Coulter and Hancké, 2016), climate action in the UK is currently on a path towards diminution.

We have proposed a range of possible outcomes of the Brexit-era for climate action. First, that there could be considerable continuity in UK climate change policy, with the UK and EU cooperating in target-setting and policy instruments. Based on the feedback in the problems stream and the lack of policy alternatives and severely limited institutional capacity to create such policy alternatives, there is considerable incentive for the UK to adopt this route. However, there is little indication within the policy stream that this will be the path chosen by the UK government. The government's express intention to "take this opportunity to develop over time a comprehensive approach to improving our environment in a way that is fit for our specific needs" (HM Government, 2017: 45) heavily indicates that the desired outcome is not a continuation of coordination and cooperation. This conclusion reinforces that the second, alternative, path is the one most likely to be pursued by the UK government. That is, that the UK will break off from the EU and forge its own path on climate action. For this second scenario there are three contrastable outcomes. First, that the UK mirrors EU climate ambition. Second, that the UK will exceed the EU's level of ambition. Third, that the UK will let its climate 
policy slip, perhaps in a bid to attract short-term economic reward. Out of these three potential outcomes, based on our analysis of the multiple streams of Brexit-era UK climate action, it is apparent that the third outcome is the most likely. Whilst EPGs within the UK are coordinating their efforts to pressure the government to adopt more environmentally-ambitious positions post-Brexit, their efforts have failed to gain the level of traction they did during the development of the CCA. Instead, due to the weaknesses of the Withdrawal Bill, key aspects of EU-level climate policy, as well as the policies that support climate and environmental policy-making, will no longer apply in the UK. This could immediately impact on the UK's ability to achieve GHGE reduction targets, damaging the UK's reputation for climate leadership. Furthermore, as the post-Brexit success of the UK has primarily been framed around future trade opportunities, it is likely that stringent climate and environmental standards will not be created, so as to not alienate potential trading partners. However, one factor that could substantially alter the current direction of postBrexit climate action is a sudden internal or external trigger that pushes climate change into both the problem and politics streams. A significant natural disaster, incontrovertibly linked to climate change, could result in a substantive shift in priorities, and would warrant a return to the multiple streams model in order to analyse its policy impact.

Whilst there are numerous questions and uncertainties surrounding the Brexit process and politics in the Brexit era, the absence of climate change from the political debates of the period is striking. The politics stream is demonstrably dominating the period. Therefore, that climate should not be a component of that stream in any substantial way indicates that considerable back-sliding on climate action could occur. Even if it is not the expressly desired outcome, the UK is currently sleep-walking into diminished climate actorness.

\section{Acknowledgements}

The authors would like to thank the two anonymous reviewers for their helpful comments and Rana Izci and James Connelly for their invitation to contribute to the special issue. 


\section{References:}

Ackrill, R. et al (2013), “Ambiguity, multiple streams, and EU policy”, Journal of European Public Policy, 20 (6): 871-87.

Babonneau, F., Haurie, A and Vielle, M. (2016) "Assessment of balanced burden-sharing in the 2050 EU climate/energy roadmap: A metamodeling approach", Climatic Change, 134 (4): 505-19.

Baumgartner, F.R. and Jones, B.D. (2009) Agendas and Instability in American Politics, 2nd edition (Chicago: The University of Chicago Press).

Béland, D. and Howlett, M. (2016) "The role and impact of the multiplestreams approach in comparative policy analysis", Journal of Contemporary Policy Analysis: Research and Practice, 18 (3): 221-27.

Buller, J. (1995) "Britain as an awkward partner: Reassessing Britain's relations with the EU", Politics, 15 (1): 33-42.

Bulkeley, H. and Kern, K. (2006) "Local government and the governing of climate change in Germany and the UK", Urban Studies, 43 (12): 2237-59.

Brunner, S. (2008) "Understanding policy change: Multiple streams and emissions trading Germany”, Global Environmental Change, 18 (3): 501-7.

Brunsden, J. and Baker, A. (2017) "EU makes contingency plans to protect carbon market from Brexit", Financial Times, 10 September 2017, $<$ https://www.ft.com/content/83443412-960e-11e7-a652cde3f882dd7b>, (23 October 2017).

Burck, J. et al (2016) "Climate Change Performance Index: Results 2017”, November 2016, <https://germanwatch.org/en/download/16484.pdf>, (12 November 2017).

Carter, N. (2014) "The politics of climate change in the UK", WIREs Climate Change, 5 (3): 423-33.

Carter, N. and Childs, M. (2017) "Friends of the Earth as a policy entrepreneur: 'The Big Ask' campaign for a UK Climate Change Act", Environmental Politics, published online ahead of print, 24 August 2017, DOI:10.1080./09644016.2017.1368151.

Carter, N. and Clements, B. (2015) "From 'greenest government ever' to 'get rid of all the green crap': David Cameron, the Conservatives and the environment", British Politics, 10 (2): 204-25.

Carter, N. and Farstad, F.M. (2017) "The Greens in the UK general election of 8 June 2017”, Environmental Politics, 26 (6): 1152-56. 
Carter, N. and Jacobs, M. (2014) "Explaining radical policy change: The case of climate change and energy policy under the British Labour government 2006-2010”, Public Administration, 92 (1): 125-41.

Clutton-Brock, P. (2017) "Catalysing cooperation: Maintaining EU-UK cooperation on energy \& climate change post-Brexit", 6 September, $<$ https://www.e3g.org/library/catalysing-cooperation-maintaining-eu-ukcooperation- on-energy-brexit>, (7 October 2017).

Committee on Climate Change (2016) "Meeting carbon budgets - Implications of Brexit for UK climate policy", October, <https:/www.theccc.org.uk/wpcontent/uploads/2016/10/Meeting-Carbon-Budgets-Implications-of-Brexitfor-UK-climate-policy-Committee-on-Climate-Change-October-2016.pdf>, (11 November 2017).

Connelly, J. (2012) "Environmental policy in the European Union and the contested notion of sustainable development", Marmara Journal of European Studies, 20 (1): 199-217.

Coulter, S. and Hanké, B. (2016) "A bonfire of the regulations, or business as usual? The UK labour market and the political economy of Brexit", The Political Quarterly, 87 (2):148-56.

Davies, W., Van Alstine, J. Lovett, J. C., (2016) “"Frame conflict' in natural resource use: Exploring framings around arctic offshore petroleum using Qmethodology", Environmental Policy and Governance, 26 (6): 482-97.

Debelke, J., Vis, P., (2015) EU Climate Policy Explained, (Abingdon: Routledge).

Demeritt, D. and Langdon, D. (2004) "The UK Climate Change Programme and communication with local authorities", Global Environmental Change, 14 (4): 325-36.

Department for Business Energy and Industrial Strategy (2017a) "2016 UK greenhouse gas emissions, provisional figures", March, <https://www. gov.uk/government/uploads/system/uploads/attachment_data/file/604408/20 16_Provisional_Emissions_statistics.pdf $>,(25$ April 2017).

Department for Business, Energy and Industrial Strategy (2017b) "Updated energy and emissions projects 2016”, March, <https://www.gov.uk/ government/uploads/system/uploads/attachment_data/file/599539/Updated_ energy_and_emissions_projections_2016.pdf>, (4 April 2017).

Department for Business, Energy and Industrial Strategy (2017c) Energy and Climate Change Public Attitudes Tracker, (London: HMSO). 
European Commission (2016) "The EU Emissions Trading System (EU ETS)". September, <https://ec.europa.eu/clima/sites/clima/files/factsheet_ets_en. pdf $>$, (17 September 2017).

European Commission (2017) "Special Eurobarometer 459: United Kingdom”, <https://ec.europa.eu/clima/sites/clima/files/support/docs/gb_cli mate_2017_en.pdf>, (2 November 2017).

Evans-Pritchard, A. (2013) "Brussels fears European 'industrial massacre' sparked by energy costs", The Telegraph, 8 September, <http://www. telegraph.co.uk/finance/financialcrisis/10295045/Brussels-fears-Europeanindustrial-massacre-sparked-by-energy-costs.html>, (2 November 2017).

Farstad, F., Carter, N., Burns, C. (2018) "What does Brexit mean for the UK's Climate Change Act?", The Political Quarterly, published online ahead of print, 19 February 2018, DOI: 10.1111/1467-923X.12486.

Gaventa, J. (2017) "How to keep up UK leadership on clean energy and climate after Brexit", February, <https://www.e3g.org/library/how-to-keep-up-ukleadership-on-clean- energy-and-climate-after-brexit>, (23 October 2017).

Grant, W., Matthews, D., Newell, P., (2000) The Effectiveness of European Union Environmental Policy, (Basingstoke: Macmillan).

Greener UK (2017) "The Repeal Bill: Securing a strong foundation for a greener UK”, June, <http://greeneruk.org/resources/GRBill_Briefing.pdf > (15 November 2017).

Hepburn, C. and Teytelboym, A. (2017) "Climate change policy after Brexit", Oxford Review of Economic Policy, 33 (1): 144-54.

Hintermann, B. (2010) "Allowance price drivers in the first phase of the EU ETS”, Journal of Environmental Economics and Management, 59 (1): 4356.

Hix, S. (2016) "Does the UK have influence in the EU legislative process?", The Political Quarterly, 87(2): 200-8.

HM Government (2017) “The United Kingdom's exit from and new partnership with the European Union”, CM 9417 (London: HMSO).

Hobolt, S. B. (2016) "The Brexit vote: A divided nation, a divided continent”, Journal of European Public Policy, 23 (9): 1259-77.

Howlett, M., McConnell, A. and Perl, A. (2015) "Streams and stages: Reconciling Kingdon and policy process theory", European Journal of Political Research, 54 (3): 419-24. 
Jessops, B. (2017) "The organic crisis of the British state: Putting Brexit in its place", Globalizations, 14 (1): 133-41.

John, P. (2006) "Explaining policy change: The impact of the media, public opinion and political violence on urban budgets in England", Journal of European Public Policy, 13 (7): 1053-68.

Jones, M. D., Peterson, H.L., Pierce, J.J., Herweg, N., Bernal, A., Raney, H.L., and Zahariadis, N. (2016) "A river runs through it: A multiple streams meta-review”, Policy Studies Journal, 44 (1): 13-36.

Jordan, A., Huitema, D., van Asselt, H., Rayner, T., and Berkhout, F. (2010) Climate Change Policy in the European Union: Confronting the Dilemmas of Migration and Adaptation?, (New York: Cambridge University Press).

Kahn, B. (2016) "The world passes 400ppm carbon dioxide threshold. Permanently", The Guardian, 28 September, <https://www.the guardian.com/environment/2016/sep/28/the-world-passes-400ppm-carbondioxide-threshold-permanently>, (11 September 2017).

Kern, K. and Bulkeley, H. (2009) "Cities, Europeanization and multi-level governance: Governing climate change through transnational municipal networks", Journal of Common Market Studies, 47 (2): 309-32.

Keskitalo, E. C., Westerhoff, L., Juhola, S. (2012) "Agenda-setting on the environment: The development of climate change adaptation as an issue in European states", Environmental Policy and Governance, 22 (6): 38194.

Kingdon, J. W. (1995) Agendas, Alternatives, and Public Policies, 2nd edition, (New York: HarperCollins College Publishers).

Lee, M., Armeni, C., de Cendra, J., Chaytor, S., Lock, S., Maslin, M., Redgwell, C., and Rydin, Y. (2012) "Public participation and climate change infrastructure", Journal of Environmental Law, 25 (1): 33-62.

Levin, K., Cashore, B., Bernstein, S., and Auld, G. (2012) "Overcoming the tragedy of super wicked problems: Constraining our future selves to ameliorate global climate change", Policy Sciences, 45 (2): 123-52.

Lovell, H., Bulkeley, H., Owens, S. (2009). "Converging agendas? Energy and climate change policies in the UK", Environment and Planning $C$ : Government and Policy, 27 (1): 90-109.

Mance, H. (2016) "Britain has had enough of experts, says Gove", Financial Times, 3 June <https://www.ft.com/content/3be49734-29cb-11e6-83e4abc22d5d108c >, (22 October 2017). 
Mintrom, M. (2000) Policy Entrepreneurs and School Choice, (Washington, DC: Georgetown University Press).

Moore, S. (2017) "The UK has become ungovernable - and no one wants to admit it", The Guardian, 8 November, <https://www.theguardian.com/ commentisfree/2017/nov/08/uk-has-become-ungovernable-no-one-wants-toadmit-it-suzanne-moore>, (14 November 2017).

Moulton, J. F. G. (2016) "European cooling on global warming? Climate change as a source of political legitimacy in the European Union", paper presented at the UACES 2016 conference: "United or Divided We Stand? Perspectives on the EU's Challenges?", VUB, Brussels, 9-10 May.

Oberthür, S. and Kelly, C.R. (2008) "EU leadership in international climate policy: Achievements and challenges", The International Spectator, 43 (3): $35-50$.

Oberthür, S. and Pallemaerts, M. (2010) "The EU's internal and external climate policies: An historical overview", in S. Oberthür and M. Pallemaerts (eds.), The New Climate Policies of the European Union: Internal Legislation and Climate Diplomacy, (Brussels: Brussels University Press), pp:27-64.

O’Brien, K. L. and Wolf, J. (2010) "A values-based approach to vulnerability and adaptation to climate change", Wiley Interdisciplinary Reviews: Climate Change, 1(2): 232-42.

O'Riordan, T. and Jordan, A. (1996) "Social institutions and climate change", in T. O'Riordan and J. Jäger (eds.), Politics of Climate Change: A European Perspective. (London: Routledge), pp: 65-105.

Petetin, L. (2017) "Written evidence submitted by Dr Ludivine Petetin", October, $<\mathrm{http}$ //data.parliament.uk/writtenevidence/committeeevidence.svc/ evidencedocument/exiting-the-european-union-committee/the-europeanunion-withdrawal-bill/written/72476.pdf>, (15 November 2017).

Rayner, T. and Jordan, A. (2011) "The United Kingdom: A paradoxical leader?" in R. Wurzel and J. Connelly (eds.), The European Union as a Leader in International Climate Change Politics, (Abingdon: Routledge), pp: 95-111.

Rayner, T. and Jordan, A. (2017) "The United Kingdom: A record of leadership under threat" in R. Wurzel, J. Connelly, D. Liefferink (eds.), The European Union in International Climate Change Politics: Still Taking a Lead?, (Abingdon: Routledge), pp: 173-188. 
Sandbag (2017) "Brexit \& the EU ETS: Greater as the Sum or in Parts?", May, $<$ https://sandbag.org.uk/wp-content/uploads/2017/05/Brexit-and-EUETSFinal-Report.pdf>, (31 May 2017).

Simms, A. (2017) "The curious disappearance of climate change, from Brexit to Berlin", The Guardian. 30 March, <https://www.theguardian.com/ environment $/ 2017 / \mathrm{mar} / 30 /$ the-curious-disappearance-of-climate-changefrom-brexit-to-berlin>, (2 November 2017).

Spohr, F. (2016) "Explaining path dependency and deviation by combining multiple streams framework and historical institutionalism: A comparative analysis of German and Swedish labour market policies", Journal of Comparative Policy Analysis: Research and Practice, 18 (3): 257-72.

Stephens, P. (2017) "Brexit has broken British politics", Financial Times, 9 November $<$ https://www.ft.com/content/8e592d24-c482-11e7-a1d2-6786f39 ef675>, (9 November 2017).

Stern, N. (2006) The Stern Review: The Economics of Climate Change, (Cambridge: Cambridge University Press).

Thatcher, M. (1989) Speech to United Nations General Assembly (Global Environment), 8 November, United Nations Building, New York.

Timothy, N. (2016) "Nick Timothy: Port Talbot, globalisation - and the governing class that gains from mass immigration while poorer people lose out”, <http://www.conservativehome.com/thecolumnists/2016/04/nicktimothy-port-talbot- should-make-us-question-the-unthinking-liberalismof-our-governing-classes.html>, (23 October 2017).

Travis, R. and Zahariadis, N. (2002) "A multiple streams model of U.S. foreign aid policy", Policy Studies Journal, 30 (4): 495-14.

Vogler, J. (2011) "The European Union as a global environmental policy actor", in R. Wurzel and J. Connelly (eds.), The European Union as a Leader in International Climate Change Politics, (Abingdon: Routledge), pp: 21-37.

Ward, B. and Carvalho, M. (2017) "Submission to the inquiry on 'Brexit: environment and climate change' by the House of Lords EU Energy and Environment Sub-Committee”, <http://www.lse.ac.uk/GranthamInstitute/ wp-content/uploads/2017/03/LSE-submission-to-HoL-brexit-inquiry_FINA L.pdf $>$, (2 November 2017).

Watson, M. (2018) "Brexit: The left behind and the let down: The political abstraction of 'the economy' and the UK's EU referendum", British Politics, 13 (1): 17-30. 
Willis, R. (2017) “Taming the climate? Corpus analysis of politicians' speech on climate change", Environmental Politics, 26 (2): 212-31.

Zohlnhöfer, R., Herweg, N., and Huß, C. (2016) "Bringing formal political institutions into the multiple streams framework: An analytical proposal for comparative policy analysis", Journal of Comparative Policy Analysis: Research and Practice, 18 (3): 243-56. 